\title{
Bioconstructions in ochreous speleothems from lava tubes on Terceira Island (Azores)
}

\author{
A. de los Ríos ${ }^{\mathrm{a}}, M^{\mathrm{a}}$ A. Bustillo ${ }^{\mathrm{b}}, \mathrm{C}$. Ascaso $^{\mathrm{a}}$ and M.R. Carvalho \\ ${ }^{a}$ Instituto de Recursos Naturales, Centro de Ciencias Medioambientales-CSIC, \\ C/Serrano 115 dpdo, 28006 Madrid, Spain. \\ ${ }^{b}$ Museo Nacional de Ciencias Naturales-CSIC, C/ José Gutiérrez Abascal 2, 28006 \\ Madrid, Spain. \\ ${ }^{c}$ Departarmento de Geologia e CeGUL, Faculdade de Ciências, Universidade de \\ Lisboa, Ed. C6 Campo Grande, 1749-016 Lisboa, Portugal.
}

\footnotetext{
*Corresponding author: A. de los Ríos. Tel.: +34 917452500; fax: +34 915640800; E-mail addresses: arios@ccma.csic.es (A. de los Rios), abustillo@mncn.csic.es (M. ${ }^{\mathrm{a}} \mathrm{A}$. Bustillo), ascso@ccma.csic.es (C. Ascaso), mdrcarvalho@fc.ul.pt (M.R. Carvalho)
} 


\section{1. Introduction}

3 Microorganisms inhabit all possible environments in the biosphere including the Earth's

4 subsurface and significantly impact its geochemistry through mineral precipitation and

5 dissolution processes (Boston et al. 2001; Northup and Lavoie, 2001; Fortin and

6 Langley, 2005; Takashima et al., 2008; Jones, 2010). In caves, mineral formations are

7 often the result of secondary mineral deposits called speleothems. The idea of a role of

8 living organisms in the development of some speleothems is fairly old but it was not

9 until the second half of the last century that evidence appeared indicating that

10 microorganisms may somehow control speleothem formation (Forti, 2001). Caves are

11 natural geomicrobiological laboratories for research on biomineralization processes and

12 the microorganism responsible for these processes, since microbial fabrics in this type

13 of environment are protected from extensive diagenetic modification or destruction

14 (Sanchez Moral et al., 2006). Resident microorganisms are commonly found in

15 speleothems (Northup et al., 2000; Kasama and Murakami, 2001; Baskar et al., 2008)

16 and bioprecipitation, biomineralization, and alteration of the rock substrate are some of

17 the mechanisms whereby these microorganisms and their metabolism can contribute to

18 mineral deposition in caves (Northup et al., 2000; Frankel and Bazylinski, 2003; Forti,

19 2005; D'Elia et al., 2007; Spear et al., 2007; Aubrecht et al., 2008; Baskar et al., 2009;

20 Jones, 2009).

21 Iron-oxidizing bacteria actively take part in the redox cycling of iron and/or the

22 precipitation of iron oxides in oxic and anoxic conditions (Kasama and Murakami,

23 2001; Barker and Banfield, 2003; Rentzt et al., 2007; Takashima et al., 2008; Baskar et

24 al., 2009; Blöthe and Roden, 2009). Iron oxide precipitation also occurs as a result of

25 passive reactions, with microbial cell walls and extracellular material acting as

26 nucleation surfaces (Fortin and Langley, 2005). Since the rate of aqueous Fe(II) 
1 oxidation and precipitation is quite low at acidic $\mathrm{pH}$ (Nordstrom and Southam, 1997), it

2 is widely recognized that microorganisms are important mediators of the oxidation of

$3 \mathrm{Fe}(\mathrm{II})$ in natural environments of low pH (Barker and Banfield, 2003; Bruun et al.,

4 2010). At neutral $\mathrm{pH}$, iron-oxidizing bacteria precipitate iron minerals at rates up to four

5 orders of magnitude higher than the inorganic precipitation rate (Kasama and

6 Murakami, 2001; Takashima et al., 2008). The community structure responsible for

7 these oxidative processes has not been completely established, but morphologically

8 distinct species such as Gallionella ferruginea and Leptothrix ochracea are generally

9 observed associated with such processes (Kennedy et al., 2003; James and Ferris, 2004;

10 Katsoyiannis and Zouboulis, 2004; Emerson and Weiss, 2004; Blöthe and Roden,

$112009)$. Studies have shown that $50-80 \%$ Fe precipitation is attributed to the metabolism

12 of microorganisms in laboratory experiments in the presence of Gallionella, Leptothrix

13 and unicellular bacteria at 3-6 ppm of Fe concentration at $\mathrm{pH}$ of 6.9-7.2 (Emerson and

14 Revsbech, 1994). In effect, Hallbeck and Pedersen (1991) reported that G. ferruginea

15 relies on $\mathrm{Fe}(\mathrm{II})$ oxidation as an electron donor for autotrophic growth. However, the

16 oxidation of Leptothrix has not been yet related to energy production or metabolic

17 utility (Kennedy et al., 2003). Other not so morphologically distinct bacteria such as

18 strains of the Proteobacteria subclass are also purportedly involved in these oxidative

19 processes (Emerson and Moyer, 1997; Brunell et al., 2006; Emerson et al., 2007; Blöthe

20 and Roden, 2009).

21 The Buracos cave developed in a lava tube on Terceira Island (Azores) (Fig. 1). The

22 island harbours four polygenetic volcanoes (Pico Alto, Santa Bárbara, Guilherme Moniz

23 and Cinco Picos) and a basalt fissure zone (Nunes, 2000, 2004; Fig. 1), which have been

24 active in the last 50,000 years (Self, 1982). The Buracos cave is sited in the Malha

25 Grande lava field, on the north flank of Santa Barbara Volcano. The cave name 
1 (buracos $=$ holes $)$ is due to the presence of several skylights along the lava tube.

2 Basaltic pyroclasts and lava flows are common, ranging in composition from basalts to

3 comendites and pantellerites (Mungall and Martin, 1995; Self, 1976). The most recent

4 eruption in 1761 gave rise to extensive flow towards the northern coastal slope. A

5 geotherm system close to the Pico Alto volcano shows superficial manifestations at the

6 Furnas do Enxofre Fumarolic field, close to the Guilherme Moniz central caldera, and

7 thermal waters in the northeast (springs) and southeast volcano flanks (wells). Buracos

8 cave is an isolated segment of the Gruta dos Balcões lava tube, the longest cave on

9 Terceira island some $5.021 \mathrm{~km}$ in length (Pereira et al., 2004), that developed in the

10 Malha Grande Lava field, $100 \mathrm{~m}$ to the west of the 1761 flow and less than $1 \mathrm{~km}$

11 northwest of the Furnas do Enxofre fumarolic field. The Buracos cave lies close to the

12 surface at a 2-3 $\mathrm{m}$ depth and is covered by the basaltic rock and a water-saturated

13 volcanic soil almost throughout the year. Abundant iron-rich speleothems including

14 stalagmites, stalactites, columns and flowstones can be found in Buracos cave.

15 This study was designed to characterize the mineralogy, chemistry and the

16 geomicrobiology of iron-rich speleothems from Buracos cave. Its main objectives were

17 to examine the microbial contribution to the fabric of iron-rich deposits and clarify the

18 role played by microorganisms in speleothem construction. The bacterial composition

19 of these speleothems was determined through a combined microscopy/molecular

20 approach.

\section{Sampling and methods}

2.1. Study Site

24 The rock forming the Buracos cave is porphyritic halocrystalline basalt containing clinopyroxene and olivine phenocrystals. The groundmass is microcrystalline and 
1 consists of acicular plagioclase, olivine, clinopyroxene and scarce opaques. The basalt is

2 scarcely altered, with only some pyroxenes and olivines having fractures presenting

3 ferric-oxides. The lava flow is covered by pumice emitted about 3000 years ago (Nunes

4 et al., 2008) and contains several basaltic lapilli deposits associated with the historic

5 eruption of $1761 \mathrm{AD}$.

6 The temperature inside the cave remains very stable, near $14^{\circ} \mathrm{C}$, and the humidity is

7 very high the year round. In the rainy season, water flows through the ceiling cracks,

8 runs off the stalactites and hits the floor. In the dry season, the dripping water from the

9 ceiling is lower, but the environmental humidity remains high. All the speleothems

10 appear wet.

11 Inside the Buracos cave, iron speleothems are stalagmites (Fig. 2A), stalactites (Fig 2A-

$12 \mathrm{C}$ ), columns and flowstones. All these formations show orange and reddish laminae

13 (Fig. 2B). Stalactites and stalagmites are very abundant, sometimes growing together

14 into columns or walls. The stalactites appeared commonly aligned along cracks (Fig

$152 \mathrm{C}$ ), with variable height (several centimeters to 2 meters). The flowstones, which reach

$16 \quad 20-30 \mathrm{~cm}$ in thickness, coat entirely the walls and the floor of the cave. The low

17 consistency of the surface oxide allows the distinction between active and inactive

18 formations. The active formations crumble easily when they are touched.

\subsection{Sampling}

21 Representative samples of ochreous speleothems were collected from an area close to 22 the entrance to Buracos cave. Half of the samples were obtained from stalactites and the 23 other from stalagmites. To examine the most modern deposits, we chose stalactites of 24 small diameter (approx. $5 \mathrm{~cm}$ ) and surface layers of stalagmites. All the speleothems 25 analyzed were soft, friable and porous and of a yellowish brown, dark brown and 26 reddish colour. Their laminated wavy structure was determined by alternations of 
1 friable, porous, yellowish brown components with thinner, harder dark brown reddish

2 bands (1-3 mm).

3

4 2.3. Mineralogical and chemical techniques

5 Whole-rock powders were prepared to determine the mineralogical and chemical

6 characteristics of the samples. Mineralogy was assessed by X-ray diffraction (XRD) of

7 pressed powder mounts using a Philips semi-automatic PW 1710 diffractometer with

8 monochromatic $\mathrm{Cu} \mathrm{K}$ radiation. Geochemical analyses were performed at Acme

9 Analytical laboratories Ltd. in Vancouver, Canada. Total abundances of major oxides

10 and minor and rare earth elements were determined by ICP-emission spectrometry and

11 ICP mass spectrometry following lithium metaborate/tetrabortate fusion and dilute nitric

12 acid digestion. Loss on ignition (LOI) was by weight difference after ignition at

$131000^{\circ} \mathrm{C}$. Details on research procedures applied to the samples is available at the

14 ACMELABS homepage: http://www.acmelab.com/.

15 The chemistry of the water related to the speleothems was determined in a sample of

16 stalactite drops by ICP-MS and ICP-OES (overrange values) at Activation Laboratories

17 Ltd., Canada.

\subsection{Electron microscopy}

20 For the study of fresh fractures, inorganic and organic materials were observed and

21 characterized in a FEI QUANTA 200 scanning electron microscope (SEM) equipped

22 with an Analytical-Inca (Oxford Instruments) analysis system incorporating an energy

23 dispersive [EDS] X-ray detector. This apparatus can be used in high vacuum, low

24 vacuum and ambient modes and is equipped with secondary electron and backscattered 
1 electron detectors. The fresh fractures of the samples were metalized with gold and

2 observed at different magnifications.

3 EDS analysis was performed at $30 \mathrm{KV}$ with a beam current of $60 \mu \mathrm{A}$. The Oxford

4 INCA software was used to acquire and process energy dispersive X-ray (EDX) spectra.

5 Atomic ratio $\mathrm{Fe} / \mathrm{Si}$ of mineral structures and precipitates were also calculated with this

6 software for comparative purpose (Kasama and Muraki, 2001; Halbberg and Ferris,

7 2004).

8 To examine cross sections, speleothem samples were prepared according to the

9 method of Wierzchos and Ascaso (1994). For the backscattered electron mode of

10 scanning electron microscopy (SEM-BSE), the rock pieces were fixed in glutaraldehyde

11 and osmium tetroxide solutions, dehydrated in a graded ethanol series and embedded in

12 LR-White resin. Blocks of resin-embedded rock samples were then polished, carbon

13 coated and viewed with a DMS 960 SEM microscope.

14 For low temperature (LT) SEM, small fragments of sample were mechanically fixed

15 onto the specimen holder of a cryotransfer system (Oxford CT1500), plunged into

16 subcooled liquid nitrogen, and then transferred to the microscope's preparation unit via

17 an air-lock transfer device. The frozen samples were cryofractured and etched for 2 min

18 at $-90^{\circ} \mathrm{C}$. After ice sublimation, etched surfaces were gold sputter coated and the

19 specimens then placed on the cold stage of the SEM chamber. Fractured surfaces were

20 observed under a DSM960 Zeiss SEM microscope at $-135^{\circ} \mathrm{C}$.

\subsection{Molecular biology techniques}

$23 P C R$. Total genomic DNA was extracted from representative speleothem samples using

24 the UltraClean Microbial DNA Isolation kit (Mobio) for subsequent PCR amplification

25 of 16S rRNA genes. Fragments of bacterial 16S rRNA genes suitable for subsequent 
1 denaturing gradient gel electrophoresis (DGGE) analysis were amplified using the

2 primer pair $341 \mathrm{fGC}$ and 907r (Muyzer et al., 1996) specific for eubacteria. $25 \mu 1$ of the

3 PCR mix [75 mM Tris $\left.\mathrm{pH} 9.0 / 50 \mathrm{mM} \mathrm{KCl} / 20 \mathrm{mM}\left(\mathrm{NH}_{4}\right)_{2} \mathrm{SO}_{4}\right]$ contained 1 unit of Taq

4 polymerase, $0.2 \mathrm{mM}$ of each of the four dNTPs, $0.4 \mu \mathrm{M}$ of each primer, $100 \mu \mathrm{g}$ of

5 bovine serum albumin, $1.5 \mathrm{mM}$ of $\mathrm{MgCl}_{2}, 5 \mu \mathrm{l}$ de $5 \mathrm{xTaq}$ Master PCR enhancer (Prime)

6 and ca $10-50$ ng genomic DNA. Annealing conditions were $60^{\circ} \mathrm{C}$. Products were

7 cleaned on a QIAGEN quick spin column (Qiagen). Both complementary strands were

8 sequenced separately at the SECUGEN sequencing company (S. L. Madrid, Spain).

9

$D G G E$. We selected a fingerprinting technique (PCR-DGGE) and sequence analysis of the resulting 16S rRNA gene bands as the best way to survey the genetic diversity of the speleothems.

Acrylamide gels (6\%) with 50 to $70 \%$ urea-formamide denaturing gradients were prepared following the manufacturer's instructions. Lanes were loaded with $22 \mu 1$ of PCR product mixed with $15 \mu 1$ of loading buffer, run at a constant $200 \mathrm{~V}$ for $7 \mathrm{~h}$ at $60^{\circ} \mathrm{C}$ and stained for visualization and photography with EtBr. Predominant bands were excised and incubated $1 \mathrm{~h}$ at $60^{\circ} \mathrm{C}$ in water prior to their use as targets for PCR amplification.

\section{Results}

\subsection{Mineralogical and bulk chemical composition}

X-ray powder diffraction analysis of the samples revealed a broad scattering band from 15 to $452 \theta^{\circ}$, peaking at around $35-362 \theta^{\circ}$ (Fig. 3), corresponding to Fe (hydr)oxides and the broad peak around $35-362 \theta^{\circ}$ defines the main reflection (about $2.50 \AA$ peak). 
1 Another broad small peak appeared at around 62-63 20 (about 1.49 A peak) defining

2 the precipitates as incipient "2-line" ferrihydrite (Fig 3) (Jambor and Dutrizac, 1998).

3 The widely reported nominal formula of ferrihydrite is $5 \mathrm{Fe}_{2} \mathrm{O}_{3} \cdot 9 \mathrm{H}_{2} \mathrm{O}$. However, there

4 is no accepted general formula since variable amounts of water can be replaced by

5 adsorbed species in quantities that cannot be accommodated within the crystalline

6 structure (Jambor and Dutrizac, 1998).

7 Bulk chemical analyses were conducted by ICP (Table I). These tests indicated that

8 the precipitates contain high $\mathrm{Fe}_{2} \mathrm{O}_{3}$ (56-59\%) concentrations along with $\mathrm{SiO}_{2}(12-16 \%)$,

9 concentrations defining the precipitates as poorly ordered Si-rich Fe-oxides/hydroxides.

$10 \mathrm{Fe}_{2} \mathrm{O}_{3} / \mathrm{SiO}_{2}$ ratios ranged from 3.44 to 4.72 . The most significant impurities were $\mathrm{Al}$,

$11 \mathrm{Mn}, \mathrm{Ca}$ and $\mathrm{Mg}$, and most abundant rare elements (up $10 \mathrm{ppm}$ ) were $\mathrm{Ba}, \mathrm{Co}, \mathrm{Sr}, \mathrm{V}, \mathrm{Zr}$,

12 Y, La, Ce, Pr, Nd, Zn and Ni.

\subsection{Chemistry of water related to the speleothems}

The stalactite drops analysis shows a very poorly-mineralized water of $\mathrm{pH}$ around 5.5 with a high (total) Fe concentration of $19.5 \mathrm{mg} / \mathrm{L}$. Further elements detected in significant amounts were: $\mathrm{SiO}_{2}(33.16 \mathrm{mg} / \mathrm{L}), \mathrm{Na}(15.1 \mathrm{mg} / \mathrm{L}), \mathrm{Mg}(5.89 \mathrm{mg} / \mathrm{L}), \mathrm{Ca}(3.1$ $\mathrm{mg} / \mathrm{L}), \mathrm{K}(2.83 \mathrm{mg} / \mathrm{L}), \mathrm{Mn}(303 \mu \mathrm{g} / \mathrm{L}), \mathrm{Br}(131 \mu \mathrm{g} / \mathrm{L}), \mathrm{Al}(65 \mu \mathrm{g} / \mathrm{L}), \operatorname{Sr}(30.3 \mu \mathrm{g} / \mathrm{L}), \mathrm{Ba}$ (20.4 $\mu \mathrm{g} / \mathrm{L}), \mathrm{Rb}(10.7 \mu \mathrm{g} / \mathrm{L}), \mathrm{Zn}(4.9 \mu \mathrm{g} / \mathrm{L}), \mathrm{Ce}(3.85 \mu \mathrm{g} / \mathrm{L}), \mathrm{La}(2.4 \mu \mathrm{g} / \mathrm{L}), \mathrm{Co}(1.89$ $\mathrm{mg} / \mathrm{L}), \mathrm{Y}(1.76 \mu \mathrm{g} / \mathrm{L}), \mathrm{Ni}(1.5 \mu \mathrm{g} / \mathrm{L})$ and $\mathrm{V}(1 \mu \mathrm{g} / \mathrm{L})$. This water chemistry reflects

21 strong leaching of basaltic pyroclasts and rocks by rainwater. This leaching could be promoted by the acid conditions of the soil (deep $\mathrm{CO}_{2}(\mathrm{~g})$ or organic source) overlying 23 the surficial basalts. 
1 The ochreous speleothems examined showed compact mineralized areas intermixed

2 with areas where bacterial structures associated with ferrihydrite deposits were

3 distinguishable. Bacterial horizons of filament-like materials were common throughout

4 the entire deposits but differences in microstructure among the different speleothems

5 were observed. Effectively, a wide morphological range of deposits could be

6 distinguished in the cross sections.

7 Microscopy revealed the laminated structure of most of the stalagmites. In some

8 zones, microstromatolites comprising alternating fine successive layers appeared at the

9 top of a stalagmite (Fig. 4). Between the different layers, micro-unconformities or

10 erosive surfaces were frequently found.

11 Through detailed observation of these microstromatolites, we were able to define the

12 following layers, which were also identified in other speleothems lacking a

13 microstromatolite structure:

14 - Type A or filamentous layer. This layer was composed of distinguishable filaments,

15 some of them prostrated or prone and lying parallel to subparallel to the deposition

16 surface; in other cases filaments appeared intermixed or disorganized. These layers were

$17 \quad 200-350 \mu \mathrm{m}$ thick.

18 - Type B or shrub layer. This layer was composed of shrub-shaped deposits formed

19 by several overlapping continuous sheets of erect branched filaments (arrows in Fig 4).

20 The thickness of each sheet varied but was in the range of $150 \mu \mathrm{m}$. This type of layer

21 was some 500-600 $\mu$ m thick.

22 - Type $\mathrm{C}$ or columnar layer. This layer was made up of columns formed by

23 overlapping convex sheets. Columns were generally wider than $100 \mu \mathrm{m}$ and their height

24 was $200 \mu \mathrm{m}$. Columns started to grow at isolated points and then packed together to

25 touch each other. Sometimes they tapered upward or ended in a rounded shape, 
1 although they often appeared truncated and superimposed on each other. The bottom of

2 the columns was more mineralized and laminations could be observed (asterisks Fig. 4).

3 This layer type was around $300 \mu \mathrm{m}$ thick.

4 - Type D or clotted layer. This layer was comprised of unorganized accumulations of 5 clots. Sometimes the clots led to the formation of mineral deposits of mound like

6 morphology (arrowheads in Fig. 4). Layer thickness was around $300 \mu \mathrm{m}$.

7 Other stalagmites did not show such clear laminated structures as the

8 microstromatolites described, but exhibited other bioconstructions such as small,

9 spherical, translucent mineral deposits (arrow in Fig. 5A). These mineral structures were 10 observed intermixed with bacterial remains and their size was in the range $20 \mu \mathrm{m}$ to 200

$11 \mu \mathrm{m}$ (Fig. 5B).

12 Stalactites showed a concentric organization of alternating layers (Fig. 5C),

13 mineralized to a lesser or greater extent, which could be broken, truncated or could

14 generate convoluted forms. Some layers were composed of prone or erected filaments

15 as the type A layer, while others intensively mineralized layers showed no clear

16 structure. In some areas, different bioconstructions were locally found: 1) various types

17 of shrub layers (arrow in Fig 5D); 2) columns and mounds similar to these observed in

18 the stromatolites; 3 ) shrub-shaped mineral deposits forming small columns over $100 \mu \mathrm{m}$

19 in height (asterisks in Fig. 5E) and cements (arrow in Fig. 5E); and 4) multilobate or

20 spheroidal ooid accumulations of clotted texture and a diameter up to $500 \mu \mathrm{m}$ (Fig. 5F).

21 Variations in morphologies and layering were observed in the stalactites and probably

22 reflect the influence of physico-chemical changes on stalactite growth. On the surface,

23 mineralization was less extensive and the bacterial mineral structures were easily

24 distinguishable (Fig. 6A). 


\subsection{Microbial components of the bioconstructions}

2 Our fresh-fracture SEM study of the speleothems confirmed observations of less dense

3 layers alternating with fully mineralized layers. In the less dense layers, filamentous

4 mineral structures and mineral precipitates could be distinguished (Fig. 6A and 6B). Fe-

5 mineral precipitates were comprised of small particles of non-defined and variable

6 shape. Some of them were rounded precipitates smaller than $1 \mu \mathrm{m}$, frequently $0.3-0.5$

$7 \mu \mathrm{m}$, grouped together to form lumps (asterisks in Fig. 6B). EDS analysis of fresh

8 fractures of the filamentous structures served to detect the presence of carbon (atomic

9 ratio $\mathrm{Fe} / \mathrm{C}=0.84 \pm 0.1$ ), which we interpret as existence of organic matter.

10 Filamentous mineral structures were of variable length (up to $30 \mu \mathrm{m}$ ) and thicknesses

11 of $5 \mu \mathrm{m}$ when thicker inorganic coatings were observed in the speleothems. The

12 filaments were straight or twisted and of variable thickness. Straight filaments in many

13 cases had an inner channel of diameter $0.18 \mu \mathrm{m}$. Twisted mineralized structures

14 resembled the stalks of Gallionella (Fig. 6B) and straight ones the sheaths of the iron-

15 oxidizing bacterium Leptothrix (Fig. 6A). The atomic ratio Fe/Si of these filamentous

16 mineralized structures revealed differences among the different layers of the

17 speleothems. In the layers of Leptothrix, the ratios obtained varied between 1.75 and

18 4.76, and in the Gallionella layers between 2.06 and 3.46. The highest atomic ratio

$19 \mathrm{Fe} / \mathrm{Si}$ of the totally mineralized areas was around 19.27.

20 In some surface areas of the speleothems, the abundant presence of extrapolymeric

21 substances associated with bacterial structures was observed by LTSEM (Fig. 6C-D).

22 Areas showing different EPS densities related to the presence of different morphotypes

23 were also observed. Thus, the Leptothrix morphotype displayed an EPS network

24 associated with the tubular sheaths (arrows in Fig. 6C) while Gallionella stalks were

25 completely covered by a denser EPS network (arrows in Fig. 6D). Mineralization of the 
1 EPS related to the cells was also observed in some areas. Mineralized cells were

2 frequently observed within a mineralized EPS matrix (arrow in Fig. 6E). The mineral

3 deposits corresponding to EPS mineralization became a dense mineralized mesh

4 (arrows in Fig. 6F).

5 Gallionella helical-like stalks showed the accumulation of granulose ferrihydrite

6 deposits in their fibres (Fig. 6B and 7A). The stalk became completely covered by these

7 deposits (Fig. 7B) in some areas. Sometimes it was possible to distinguish a gradient of

8 mineralization when moving away from a mineralized compact layer, with decreases in

9 compaction and increases in independent mineralized structures (Fig. 7C). Different

10 phases of mineralization could be discerned in this spatial gradient. Stalks with some

11 mineral deposits were observed in phase I (Fig. 7A). Individualized mineralized

12 bacterial structures that were however completely covered by ferrihydrite deposits were

13 the predominant components of phase II (Figs. 7B, 7D). In phase III, groups of

14 mineralized bacterial structures formed compact masses but individual mineralized

15 remains were also visible (Fig. 7C). Phase IV corresponded to the compact mineralized

16 layer (Fig. 7C). Dense spheres deposits seemed also to be formed by the accumulation

17 of Gallionella mineral encrusted stalks showing an outer radially organized band (Figs

$18 \quad 5 \mathrm{~F}$ and 7E). In all stages, mineral precipitates associated with the stalks showed Fe and

$19 \mathrm{Si}$ as their main components (Fig. 7F).

20 Most intense mineralization associated with the Leptothrix morphotype consisted of

21 the formation of a thick mineral layer rich in Fe and also containing Si coating entirely

22 the filamentous structures (Fig. 7G and 8A). EPS were also visualized in the proximity

23 of the mineralized structures (arrows in Fig. 8B). Higher atomic Fe/Si ratios (2.44

$24 \pm 0.11)$ due to higher amounts of Fe were detected in the sheaths covered by a wide

25 external mineralized layer compared to naked sheaths $(1.86 \pm 0.105)$. The accumulation 
1 of mineral-encrusted sheaths produced smooth mineral deposits (arrow in Fig. 8C). In

2 other areas, only the build-up of broken naked sheaths was observed (arrow in Fig. 8D).

3 Spherical translucent mineral deposits, observed in some speleothems, seemed to be

4 associated with the presence of Leptothrix and mineralized EPS (Fig. 5B).

5 Alternative layers composed of the two morphotypes could be observed (Fig. 8E), but

6 it was also frequent to find both morphological types intermixed to generate mixed

7 mineral deposits (Fig. 8F).

8 Our DGGE results indicated that these bioconstructions contained different bacterial

9 phylotypes (Fig. 9). Different DGGE profiles were obtained for each speleothem, 10 although some bands were common to both. The main DGGE bands (in terms of 11 intensity) were excised, reamplified and sequenced, though we could not always obtain 12 good sequences. Four different sequences were obtained from the excised stalagmite 13 DGGE bands and 3 from the stalactite DGGE bands, corresponding with the most 14 predominant bands in both DGGE profiles. BLAST analysis of the sequences indicated 15 that most band sequences corresponded to Proteobacteria (Table II). Leptothrix and 16 Gallionella sequences were not obtained.

\section{Discussion}

20 The structures and minerals observed in the speleothems revealed their biogenic origin.

21 The mineral deposits observed were the result of agglutination of specific bacterial

22 structures and close associated ferrihydrite deposits. The microorganisms detected form biofabrics organized in arrays of cells and associated mineral microstructures that

24 confer structural strength to the mineralized component (Spear et al., 2007). The 
1 morphotypes Gallionella and Leptothrix were most frequently observed in these

2 speleothems.

3 In some samples, the morphotype Gallionella dominated and could be identified by

4 its distinctive stalk in the form of bundled fibres arranged as a double helix (Fig. 6B).

5 Some stalks were almost free of iron precipitates (Fig. 7A) and presumably represent

6 younger segments of stalk closer to the apical cells (Hallberg and Ferris, 2004); others

7 were completely encrusted with these precipitates (Fig. 7B). Iron precipitate formation

8 thus appears to start inside the fibre, where the organic structure may act as a template

9 for crystallization (Warren and Ferris, 1998). Later crystals begin to develop on the

10 outside and the whole stalk becomes encrusted (Hallberg and Ferris, 2004). Leptothrix

11 formed very fine tubular structures composed of Fe-oxihydroxides (Fig. 6A) that could

12 transform into heavily encrusted forms (Fig. 8A). Impregnation and encrusting of the

13 sheaths and stalks with iron probably takes place after the cells have left the envelopes

14 or stalks, when a passive process cannot be ruled out (Emerson and Weiss, 2004). The

15 presence of the sheath and build-up of ferrihydrite in the stalk offers several advantages

16 for persisting in this environment, since it prevents the living cell from becoming

17 encrusted (Fortin and Langley, 2005; Takshima et al., 2008). In addition, other

18 mechanisms such as solubilization by complexation, creation of specific cellular $\mathrm{pH}$

19 microenvironments, modification of the cell surface charge, and production of cellular

20 exopolymers that act as precipitation templates could also be involved in cell protection

21 (Schädler et al., 2009).

22 We did not detect an evident population of living cells of the genera Gallionella or

23 Leptothrix in the speleothems. This is probably why these species did not appear as

24 predominant bands in the DGGE profiles obtained. Other authors have also reported

25 difficulties in detecting the presence of these species using molecular methods 
1 (Takashima et al., 2008; Bruun et al., 2010). The latter authors proposed the presence of

2 sheaths as the reason for not being able to recover DNA from Leptothrix-like cells

3 (Bruun et al., 2010). In addition, most of the cells of these genera present in the

4 speleothem are probably not alive because only the associated mineral structures were

5 visualized. Living cells seem to be present only in outer layers. Our DGGE analysis

6 yielded a profile dominated by proteobacteria (Table II). Several proteobacteria have

7 also been incriminated in Fe oxidation processes (Bruneel et al., 2006; Emerson et al.,

8 2007). Thus, a significant number of proteobacterial $16 \mathrm{~S}$ rRNA gene sequences may be

9 found in the clone library of a circumneutral-pH groundwater Fe seep (Blöthe and

10 Roden, 2009). Our DGGE analysis also revealed the presence of other uncultured

11 bacterial groups related to the Fe cycle, such as those of the Actinobacteria group. The

12 production of mineral structures showing Gallionella and Leptothrix morphotypes and

13 their capacity to precipitate ferrihydrite makes them likely candidates as main

14 contributors to the formation of these speleothems. Effectively, Gallionella sp. and

15 Leptothrix sp. are the most commonly observed bacteria associated with biogenic iron

16 oxides in neutral $\mathrm{pH}$ environments (Emerson and Weiss, 2004). Hence, iron oxide

17 particles in the close vicinity of Leptotrhix sheaths and Gallionella stalks and their

18 exopolymers may be referred to as extracellular biogenic iron oxides (Fortin and

19 Langley, 2005). However, we cannot rule out a role of a unicellular unsheathed species

20 detected by DGGE, which although not responsible for the iron precipitates encrusting

21 Leptothrix sheaths and associated with Gallionella stalks could contribute to iron

22 precipitates showing a patchy distribution (Fortin and Langley, 2005).

23 Leptothrix and Gallionella are large producers of exopolymeric substances (EPS)

24 associated with the sheath and stalk, respectively (Fig. 6C and 6D). EPS are important

25 surface reactants that can bind or nucleate Fe minerals (Fein et al., 1997; Yee and Fein, 
1 2001; Daughney et al., 2001; Chatellier and Fortin, 2004; Chan, 2004; Fortin and

2 Langley, 2005; Miot et al., 2009). The close association between EPS and mineralized

3 cells as well as the detection of mineralized EPS (Fig. 6E and 6F) support the

4 hypothesis that they play a key role in ferrihydrite accumulation. In effect, the presence

5 of EPS and features of these microorganism surfaces have been described as the main

6 factors determining organic Fe precipitation rates in Fe-stalactites (Kasama and

7 Murakami, 2001). The type of mineralization observed in both morphotypes is clearly

8 determined by their different cell structures but could also be influenced by the

9 observed differences in the EPS network (Fig. 6C and 6D).

10 Independently of the taxa present, mineral accumulations were composed of poorly

11 ordered Si-rich ferrihydrite. Ferrihydrite is one of the most common minerals found in

12 association with active microbial iron oxidation in circumneutral freshwater systems

13 (Konhauser, 1998; Langley et al. 2009). According to our knowledge of ferrihydrite, it

14 seems that $\mathrm{Si}$ is incorporated in the iron oxihydroxides by microbial activity (Emerson

15 and Moyer, 1997). Ferrihydrite is the normal precipitate if the oxidation/precipitation

16 reaction is fast and there are small amounts of silicate present (Cornell and

17 Schwertmann, 1996). According to Kennedy et al. (2003), the adsorption of Si to iron

18 oxide-encrusted bacterial surfaces give stability of two-line ferrihydrite, in that the

19 natural conversion to more crystalline iron oxides such as hematites and goethite is

20 avoided. This stability of ferrihydrite explains the well-preserved morphology of

21 bacterial sheaths and stalks observed in this study. We also detected distinct $\mathrm{Fe} / \mathrm{Si}$

22 atomic ratios for different layers, suggesting that during speleothems formation this

23 ratio could change. Silicon was homogeneously dispersed throughout the initial

24 precipitates, presumably via Fe-O-Si bonding, but in compact red layers, the ratio was 
1 higher due to Fe-rich late-stage cementation. This later cementation could be key for the

2 consistency of the speleothems.

3 The structure of the speleothems analyzed seems to be conditioned by the type of

4 bacteria present and level of mineralization. The biomineralization patterns shown by

5 the two morphotypes revealed the role of bacterial metabolism in the mineralization

6 process although with differences between morphotypes, which could relate to different

7 metabolic and morphological features (Miot et al., 2009). The EPS matrix associated to

8 both morphotypes could also play a major role in developing specific textures (Handley

9 et al., 2008). Hence, it was possible to correlate some of the bioconstructions to a given

10 morphotype. For example, translucent spherical structures were ascribed to Leptothrix

11 (Fig. 5B), and dense spheres (Fig. 5F) and some shrubs and columnar formations to

12 Gallionella. Other formations could be the result of a mixture of both morphotypes (Fig.

13 4). Thus, the greater or lesser presence of a given morphotype during speleothem

14 formation could condition the presence of different textures and the formation of

15 specific layers. Bacterial mineralized structures and their associated mineral deposits

16 such as shrubs, mounds and columns were frequently organized according to the

17 boundaries of the layers. In addition, the upper limits of some of the growth layers were

18 truncated or severely corroded, possibly because of subaerial exposure stages (Fig. 4).

19 Fully mineralized layers formed through the accumulation of these mineral bacterial

20 structures and later cementation processes. The observation of bacterial remains in all

21 the layers enables us to rule out the possibility of periodic pure inorganic precipitation

22 as the origin of the compact mineral layers, but we cannot discard the contribution of

23 some inorganic passive precipitation. Acid leaching of basaltic soils and rocks causes

24 intense Fe and Si enrichment of subsurface water. Variations in redox conditions during

25 water flow into a cave, causes oversaturation of the water related to Fe-(hydr)oxides and 
1 could lead to mineral precipitation at neutral $\mathrm{pH}$ (Kirby and Elder Brady, 1998). The

2 amount of $\mathrm{Fe}$ in the cave water $(19.5 \mathrm{mg} / \mathrm{l})$ was sufficient for the inorganic precipitation

3 of ferrihydrite but not for this to become the dominant process (Phoenix et al., 2003).

4 Since microbially mediated $\mathrm{Fe}+$ oxidation can inhibit the inorganic chemical oxidation

5 of $\mathrm{Fe}$ (Emerson and Revsbech, 1994), the inorganic contribution to the mineralization

6 observed could be low. A lack of substances essential for bacteria, such as Fe(II),

7 dissolved oxygen or nutrients, could regulate their life cycle and activity and,

8 consequently, the deposition of mineral bacterial structures and speleothem formation

9 (Takashima et al., 2008). However, since the biogenic minerals detected are not only the

10 result of direct bacterial metabolic activity but also contribute to passive sorption and

11 nucleation reactions (Kasama and Murakami, 2001; Baskar et al., 2008), the

12 contribution of $\mathrm{Si}$ and $\mathrm{Fe}$ in interstitial water could also be a determining factor in the

13 mineralization phase and consequently in speleothem microstructure. Variations in the

14 water deficit or acid contributions (related to seasonal changes or $\mathrm{CO}_{2}$ flux) cause water

$15 \mathrm{pH}$ modifications promoting changes in organic/inorganic precipitation reactions.

16 Many authors argue it is difficult to clearly differentiate between true biogenic

17 Fe-oxides and those formed as a result of abiotic reactions in natural samples containing

18 neutrophilic Fe-oxidizers (Fortin and Langley, 2005). However, by exploring

19 relationships between mineral precipitates and microorganisms and their structures

20 using high-resolution microscopy techniques, we infer an important role of bacteria in

21 the construction of these speleothems. 


\section{5. Conclusions}

2 - The speleothems examined are comprised of accumulations of specific bacterial

3 structures (mainly Gallionella and Leptothrix morphotypes) and ordered Si-rich

4 ferrihydrite deposits (incipient 2-line ferrihydrite). Successive microbial growth and its

5 associated mineral precipitation causes the growth of these speleothems.

6 - The structure of the speleothems analyzed seems to be conditioned by the type bacteria

7 present (structural and metabolic features) and level of mineralization. Some of the

8 bioconstructions can be assigned to one morphotype such as the translucent spherical

9 structures to Leptothrix and dense spheres and some shrubs and columnar formations to

10 Gallionella. Other formations could be the result of mixture of both morphotypes

11 - Bacterial activity seems to be the main determinant of speleothem structure. Through

12 their metabolism, bacteria precipitate siliceous ferrihydrite but their mineral structures

13 and associated EPS matrix also act as nucleation points for a subsequent passive mode

14 of mineral precipitation. The observation of bacterial remains in most of the speleothem

15 layers precludes the possibility of periodic climatic pure inorganic precipitation. Factors

16 affecting the life cycle and activity of the bacteria could conditionate the deposition of

17 mineral bacterial structures and consequently the spelotherm structure.

18 - Accumulation of bacterial mineral structures and later inorganic cementation are

19 finally responsible for the formation of consistent mineral layers, conferring consistency

20 to the speleothems.

21 - Independent of the taxa present, the mineral precipitates were siliceous ferrihydrite but

22 differences in Fe/Si atomic ratios have been found. The compact mineralized structures

23 were richer in Fe than independent bacterial structures, indicating a Fe-rich late

24 cementation. 
1 - Acid leaching of basaltic soils and rocks caused intense Fe and Si enrichment of

2 subsurface water, leading the observed biogenic siliceous ferrihydrite precipitation at

3 slightly acid or circumneutral ph environment.

4

\section{Acknowledgements}

7 The authors thank Fernando Pinto, $\mathrm{M}^{\mathrm{a}}$ Teresa Carnota, $\mathrm{M}^{\mathrm{a}}$ Jose Malo, Laura Tormo,

8 Alberto Jorge and Marta Furio for their technical assistance, and Ana Burton for

9 reviewing the English. This work was supported by grants CTM2009-12838-CO4-O3

10 and CGL2008-05584-CO-2-01 from the Spanish Ministry of Science and Innovation.

References

13

14 Aubrecht, R., Brewer-Carias, C., Smida, B., Audy, M., Kovacik, L. 2008. Anatomy of 15 biologically mediated opal speleothems in the World's largest sandstone cave: Cueva

16 Charles Brewer, Chimanta Plateau, Venezuela. Sedimentary Geology 203, 181-195.

17 Baskar, S., Baskar, R., Lee, N., Kaushik, A., Theophilus, P. 2008. Precipitation of iron in 18 microbial mats of the spring waters of Borra Caves, Vishakapatnam, India: some 19 geomicrobiological aspects. Environmental Geology and Water Sciences 56, 23720243.

21 Baskar, S., Baskar, R., Lee, N., Theophilus, P. 2009. Speleothems from Mawsmai and 22 Krem Phyllut caves, Meghalaya, India: some evidences on biogenic activities. 23 Environmental Geology and Water Sciences 57, 1169-1186.

24Blöthe, M., Roden, E.E. 2009. Microbial iron redox cycling in a circumneutral-pH 25 groundwater seep. Applied and Environmental Microbiology 75, 468-473.

26Boston, P.J., Spilde, M.N., Northup, D.E., Melim, L.A., Soroka, D.S., Kleina, L.G., Lavoie, 27 K.H., Hose, L.D., Mallory, L.M., Dahm, C.N., Crossey, L.J., Schelble, R.T. 2001.

28 Cave biosignature suites: microbes, minerals, and Mars. Astrobiology 1, 25-55.

29Bruneel, O., Duran, R., Casiot, C., Elbaz-Poulichet, F., Personné, J.C. 2006. Diversity of 30 microorganisms in Fe-As-Rich acid mine drainage waters of Carnoules, France.

31 Applied and Environmental Microbiology 72, 551-556.

32 Bruun, A., Finster, K., Gunnlaugsson, H., Nornberg, P., Friedrich, M. 2010. A comprehensive investigation on iron cycling in a freshwater seep including 
1 microscopy, cultivation and molecular community analysis. Geomicrobiology Journal $2 \quad 27,15-34$.

3 Chan, C. 2004. Microbial polysaccharides template assembly of nanocrystal fibers. Science 4 303, 1656-1658.

5 Chatellier, X., Fortin, D. 2004. Adsorption of ferrous ions onto Bacillus subtilis cells.

6 Chemical Geology 212, 209-228.

7 Cornell, R.M., Schwertmann, U. 1996. The iron oxides: VCH Verlagsgesellschaft, 8 Weinheim.

9Daughney, C.J., Fowle, D.A., Fortin, D. 2001. The effect of growth phase on proton and 10 metal adsorption by Bacillus subtilis. Geochimica et Cosmochimica 65, 1025-1035.

11 D'Elia, M., Quarta, G., Calcagnile, L., Belmonte, G. 2007. Study of the formation of 12 biogenic speleothems found in submarine caves at the Cape of Otranto, Italy, by ${ }^{14} \mathrm{C}$ 13 AMS. Nuclear Instruments and Methods in Physics Research Section B: Beam 14 Interactions with Materials and Atoms 259, 395-397.

15Emerson, D., Moyer, C. 1997. Isolation and characterization of novel iron-oxidizing 16 bacteria that grow at circumneutral $\mathrm{pH}$. Applied and Environmental Microbiology 63, 17 4784-4792.

18Emerson, D., Rentz, J.A., Lilburn, T.G., Davis, R.E., Aldrich, J.E., Chan, C., Moyer, C.L. 19 2007. A novel lineage of proteobacteria involved in formation of marine Fe-oxidizing 20 microbial mat communities. Plos one 2: e667. doi:610.1371.

21 Emerson, D., Revsbech, N.P. 1994. Investigation of an iron-oxidizing microbial mat 22 community located near Aarhus Denmark: field studies. Applied and Environmental 23 Microbiology 60, 4022-4031.

24Emerson, D., Weiss, J.V. 2004. Bacterial iron oxidation in circumneutral freshwater 25 habitats: findings from the field and from laboratory. Geomicrobiology Journal 21, 26 405-414.

27Fein, J.B., Daughney, C.J., Yee, N., Davis, T.A. 1997. A chemical equilibrium model for 28 metal adsorption onto bacterial surfaces. Geochimica et Cosmochimica Acta 61, $29 \quad 3319-3328$.

30Forti, P. 2001. Biogenic speleothems: an overview. International Journal of Speleology 1/4, $3139-56$.

32Forti, P. 2005. Genetic processes of cave minerals in volcanic environments: an overview. 33 Journal of cave and karst studies 67: 3-13.

34Fortin, D., Langley, S. 2005. Formation and occurrence of biogenic iron-rich minerals. 35 Earth-Science Reviews 72, 1-19.

36Frankel, R.B., Bazylinski, D.A. 2003. Biologically induced mineralization by bacteria. 37 Reviews in Mineralogy and Geochemistry 54, 217-247.

38 Hallbeck, L., Pedersen, K. 1991. Autotrophic and mixotrophic growth of Gallionella 39 ferruginea. Journal of General Microbiology 137, 2657-2661. 
1 Hallberg, R., Ferris, F.G. 2004. Biomineralization by Gallionella. Geomicrobiology Journal $2 \quad 21,325-330$.

3 Handley, K.M., Turner, S.J., Campbell, A., Mountain, B.W. 2008. Silicifying biofilm

4 exopolymers on a hot spring microstromatolite: Templating nanometer-thick laminae.

5 Astrobiology 8, 747-770.

6James, R.E., Ferris, F.G. 2004. Evidence for microbial-mediated iron oxidation at a

7 neutrophilic groundwater spring. Chemical Geology 212, 301-311.

8 Jambor, J.L., Dutrizac, J.E. 1998. Occurrence and Constitution of Natural and Synthetic

9 Ferrihydrite, a Widespread Iron Oxyhydroxide. Chemical Reviews 98, 2549-2585.

10 Jones, B. 2009. Cave pearls-the integrated product of abiogenic and biogenic processes.

11 Journal of sedimentary research. Section A, Sedimentary petrology and processes 79, $12 \quad 689-710$.

13 Jones, B. 2010. Microbes in caves: agents of calcite corrosion and precipitation. Geological 14 Society, London, Special publications 336, 7-30.

15 Kasama, T., Murakami, T. 2001. The effect of microorganisms on Fe precipitation rates at 16 neutral pH. Chemical Geology 180, 117-128.

17 Katsoyiannis, I.A., Zouboulis, A.I. 2004. Biological treatment of Mn(II) and Fe(II)

18 containing groundwater: kinetic considerations and product characterization. Water

19 Research 38, 1922-1932.

20 Kennedy, C.B., Scott, S.D., Ferris, F.G. 2003. Ultrastructure and potential sub-seafloor 21 evidence of bacteriogenic iron oxides from Axial Volcano, Juan de Fuca Ridge, 22 north-east Pacific Ocean. FEMS Microbiology Ecology 43, 247-254.

23 Kirby, C.S., Elder Brady, J.A. 1998. Field determination of Fe2+ oxidation rates in acid 24 mine drainage using continuously stirred tank reactor. Applied Geochemistry 13, $25 \quad 509-520$

26 Konhauser, K.O. 1998. Diversity of bacterial iron mineralization. Earth-Science Reviews $27 \quad 43,91-121$.

28Langley, S., Gault, A., Ibrahim, A., Renaud, R., Fortin, D., Clark, I. 2009. A comparison of 29 the rates of $\mathrm{Fe}(\mathrm{III})$ reduction in synthetic and bacteriogenic iron oxides by Shewanella 30 putrefaciens CN32. Geomicrobiology Journal 26, 57-70.

31 Miot, J., Benzerara, K., Morin, G., Kappler, A., Obst, M., Brown, G. 2009. Iron

32 biomineralization by neutrophilic nitrate-reducing iron-oxidizing bacteria.

33 Geochimica et Cosmochimica Acta 73, A884-A884.

34 Mungall, J., Martin, R. 1995. Petrogenesis of basalt-comendite and basalto-pantellerite 35 suites, terceira, azores, and some implications for teh origino f ocean-island rhyolites.

36 Contributions to Mineralogy and Petrology 119: 43-55.

37 Muyzer, G., Hottenträger, S., Teske, A., Wawer, C. 1996. Denaturating gradient gel 38 electrophoresis of PCR-amplified 16S rDNA- A new molecular approach to analyse 39 the genetic diversity of mixed microbial communities. In: Akkermans, A.D.L., van 40 Elsas, J.D., de Bruijn, F.J. (Eds.), Molecular Microbial Ecology Manual 2nd: Kluwer 
1 Academic Publishers, Dordrecht, pp. 3.4.4.1-3.4.4.23.

2 Nordstrom, D.K., Southam, G. 1997. Geomicrobiology of sulfide mineral oxidation.

3 Reviews in Mineralogy and Geochemistry 35, 361-390.

4 Northup, D.E., Dahm, C.N., Melim, L.A., Spilde, M.N., Crossey, L.J., Lavoie, K.H., 5 Mallory, L.M., Boston, P.J., Cunningham, K.I., Barns, S.M. 2000. Evidence for 6 geomicrobiological interactions in Guadalupe caves. Journal of Cave and Karst 7 Studies 62: 80-90.

8 Northup, D., Lavoie, K. 2001. Geomicrobiology of caves: a review. Geomicrobiology 9 Journal 18, 199-222.

10Nunes, J.C. 2000. Notas sobre a geologia da Terceira. Açoreana, 9: 205-215.

11 Nunes J.C. 2004. Geologia. In: Forjaz, V.H. (Ed.) Atlas Básico dos Açores: Observatório

12 Vulcanológico e Geotérmico dos Açores, Ponta Delgada, pp. 60-62.

13 Nunes, J.C., Garcia, P., Lima, E.A, Costa, M.P. Pereira, F. (2008). New Geological Insights

14 for the Azores Islands (Portugal) Lava Caves. XIII International Symposium on

15 Vulcanospeleology Jeju Island - Korea.

16Pereira, F., Barcelos, J.M., Botelho, L., Bettencourt, L., Borges, P. 2004. The complex of

17 Malha, Buracos and Balcones caves (Terceira, Azores). In: Abstracts-XIth

18 International Symposium on Volcanospeleologyâ. Maio. Madalena. Pico, pp. 68.

19 Phoenix, V.R., Konhauser, K.O., Ferris, F.G. 2003. Experimental study of iron and silica

20 immobilization by bacteria in mixed Fe-Si systems: implications for microbial

21 silicification in hot springs. Journal of Earth Science 40, 1669-1678.

22 Rentz, J.A., Charoenkwan, K., Luther, G.W., Emerson, D. 2007. Control of ferrous iron

23 oxidation within circumneutral microbial iron mats by cellular activity and

24 autocatalysis. Environmental Science and Technology 41, 6084-6089.

25 Sanchez-Moral, S., González, J.M., Cañaveras, J.C., Cuezva, S., Lario, J., Cardell, C., Elez,

26 J., Luque, L., Saiz-Jiménez, C. 2006. Procesos de precipitación mineral bioinducidos

27 en sistemas kársticos subterráneos: breve revisión y nuevas tendencias. Estudios

28 Geológicos 62, 43-52.

29 Schädler, S., Burkhardt, C., Hegler, F., Straub, K.L., Miot, J., Benzerara, K., Kappler, A.

30 2009. Formation of cell-iron-mineral aggregates by phototrophic and nitrate-reducing

31 anaerobic Fe(II) -oxidizing bacteria. Geomicrobiology Journal 26, 93-103.

32 Self, S. 1976. The recent volcanology of Terceira, Azores. Journal of Geological Society

33 132, 645-666.

34 Self, S. 1982. Excursion Guide for field trip V2. Island of Terceira. Arquipélago 3, 32935342.

36 Spear, J.R., Barton, H.A., Robertson, C.E., Francis, C.A., Pace, N.R. 2007. Microbial

37 community biofabrics in a geothermal mine audit. Applied and Environmental

38 Microbiology 73, 6172-6180.

39 Takashima, C., Kano, A., Naguma, T., Tazaki, K. 2008. Laminated iron texture by iron40 oxidizing bacteria in calcite travertine. Geomicrobiology Journal 25, 193-202.

41 Warren, L.A., Ferris, F.G. 1998. Continuum between sorption and precipitation of Fe(III) 42 on microbial surfaces. Environmental Science and Technology 32, 2331-2337.

43 Wierzchos, J., Ascaso, C. 1994. Application of back-scattered electron imaging to the st 44 udy of the lichen rock interface. Journal of Microscopy 175, 54-59. 
2 Yee, N., Fein, J. 2001. Cd adsorption onto bacteria surfaces: a universal adsorption edge? 3 Geochimica et Cosmochimica Acta 65, 2037-2042. 


\section{Legends}

3 Fig 1. Geological map of Terceira Island (adapted from Nunes 2004) showing the 4 location of Buracos cave.

6 Fig 2. (A) Stalagmites and stalactites from Buracos cave. (B) Sample of the lower 7 apical section of a small stalactite in the Buracos cave. (C) Aligned stalactites along a 8 crack in Buracos cave.

9

10 Fig 3. Powder X-ray diffraction patterns for the ferrihydrite, showing a broad scattering 11 band between 15 and $452 \mathrm{q}^{\circ}$ with two broad main peaks.

13 Fig 4. SEM-BSE image of a microstromatolite structure from a stalagmite in which

14 different layer types (A, B, C, D) may be distinguished. Arrows indicate clotted mineral 15 accumulations, arrowheads shrub-shaped accumulations and asterisks colomunar 16 formations.

18 Fig 5. (A) SEM-SE image of a stalagmite showing spherical translucent mineral deposits (arrow). (B) Detailed SEM-SE image of the deposits observed in A. (C) SEM-

20 BSE image of a stalactite showing the concentric organization of alternating layers. (D)

21 SEM-SE image of shrub-shaped mineral deposits (arrows) in a stalactite. (E) SEM-BSE 22 image of the columnar layer of a stalactite showing columns (asterisks) and cementation 23 (arrows). (F) SEM-BSE image of spheroidal ooid deposits of clotted texture in a sample 24 taken from a stalactite. 
1 Fig 6. Electron microscopy images of bacterial structures. (A) SEM-SE image of a fresh

2 fracture of a superficial layer of Leptothrix filaments. (B) SEM-SE image of a fresh

3 fracture of an area harbouring the Gallionella morphotype. Asterisk indicates rounded

4 Fe minerals. (C, D) LTSEM images of Leptotrhix (C) and Gallionella (D) morphotypes

5 and their associated EPS matrix (arrows). (E, F) Bacterial structures and EPS matrix

6 showing the first phases of mineralization (arrows) visualized by SEM-BSE (E) and

$7 \quad \operatorname{LTSEM}(\mathrm{F})$.

9 Fig 7. (A-E) SEM-BSE images of layers rich in Gallionella morphotypes. Gallionella

10 helical-like stalks showing the initial accumulation of granulose ferrihydrite deposits in

11 their fibres (A) and their complete covering by these deposits (B). (C) Gradient of

12 mineralization associated with the presence of a mineralized compact layer. (D)

13 Detailed image of the mineral structures comprising phases II and III. (E) Detailed

14 image of an ooid mineral deposit formed by compaction of Gallionella mineral

15 encrusted stalks. Note the outer part shows a radial organization. (F-G) Fe and Si

16 distribution map obtained by EDS analysis of structures of Gallionella (F) and

17 Leptothrix (G).

19 Fig 8. (A-B) Images of mineralized Leptothrix filaments visualized by SEM-BSE (A) and LTSEM (B). Arrows indicate EPS. (C) LTSEM image of accumulated mineral

21 encrusted Leptothrix filaments. (D) SEM-BSE image of accumulated broken naked

22 Leptothrix sheaths (arrow). (E) SEM-BSE image of alternating mineralized Leptothrix

23 (L) and Gallionella $(\mathrm{G})$ layers. (F) SEM-BSE image of mixed mineral deposits

24 containing both morphological types. Black arrows note Gallionella deposits and white

25 Leptothrix deposits. 
2 Fig 9. Denaturing gradient gel electrophoretic profile of PCR-amplified 16S rRNA gene

3 fragments obtained from representative stalagmite (STM) and stalactite (STC) samples

4 using the bacterial primers $341 \mathrm{fGC}$ and $907 \mathrm{r}$.

5 
2

3

4 Table I: Total abundances of major oxides obtained by ICP-emission spectrometry

5

6

7 Table II: Codes (DGGE bands), accession numbers and closest relatives for the bacterial

8 DGGE bands shown in Fig. 9.

9 


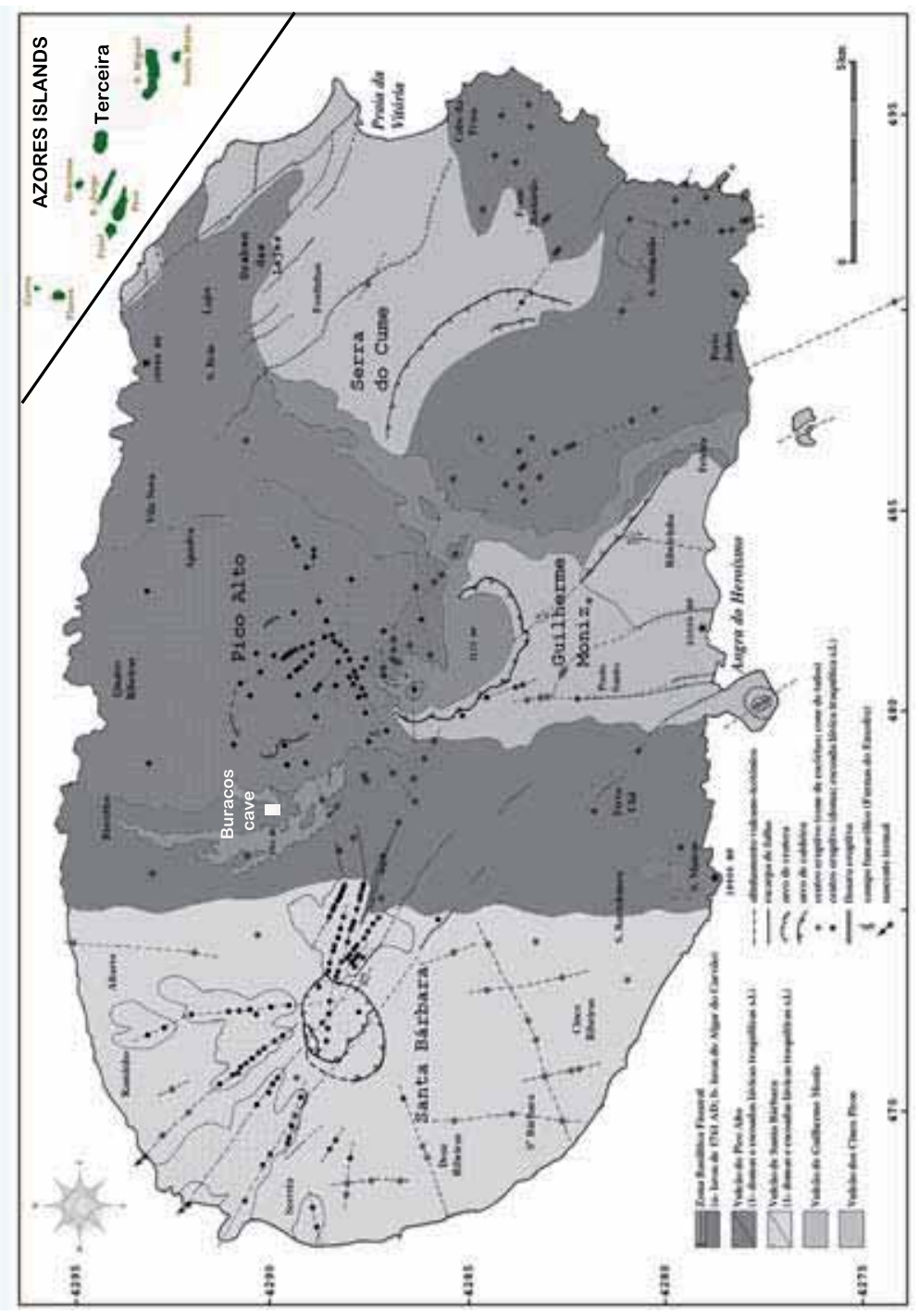



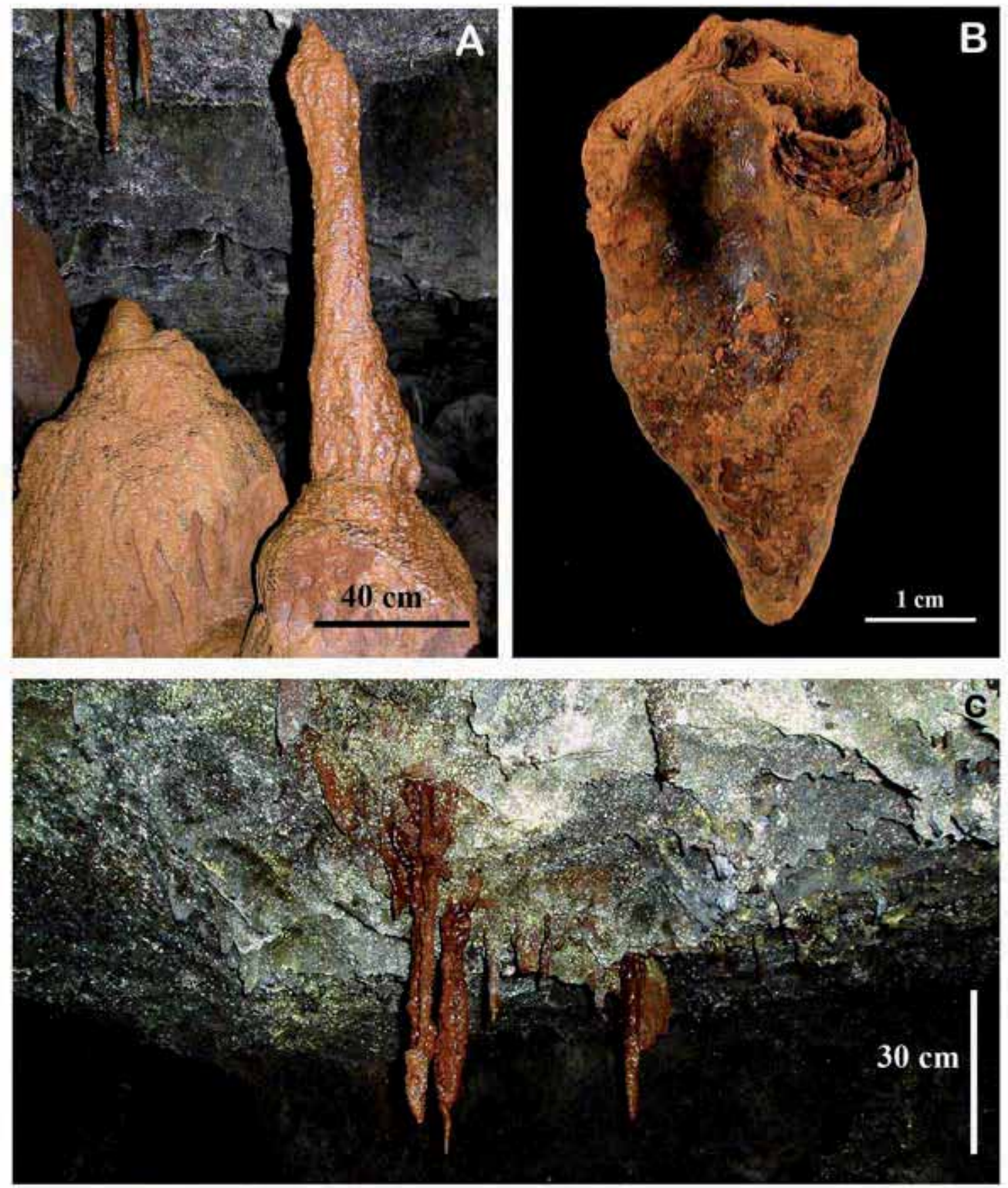


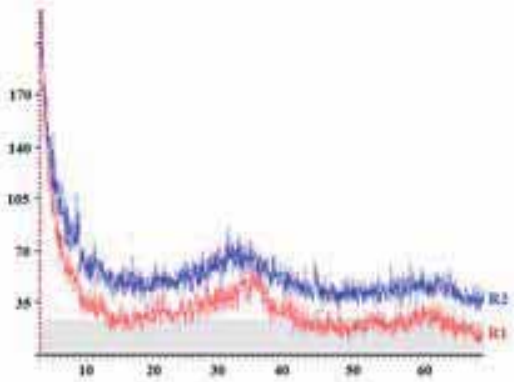

Fig. 3 


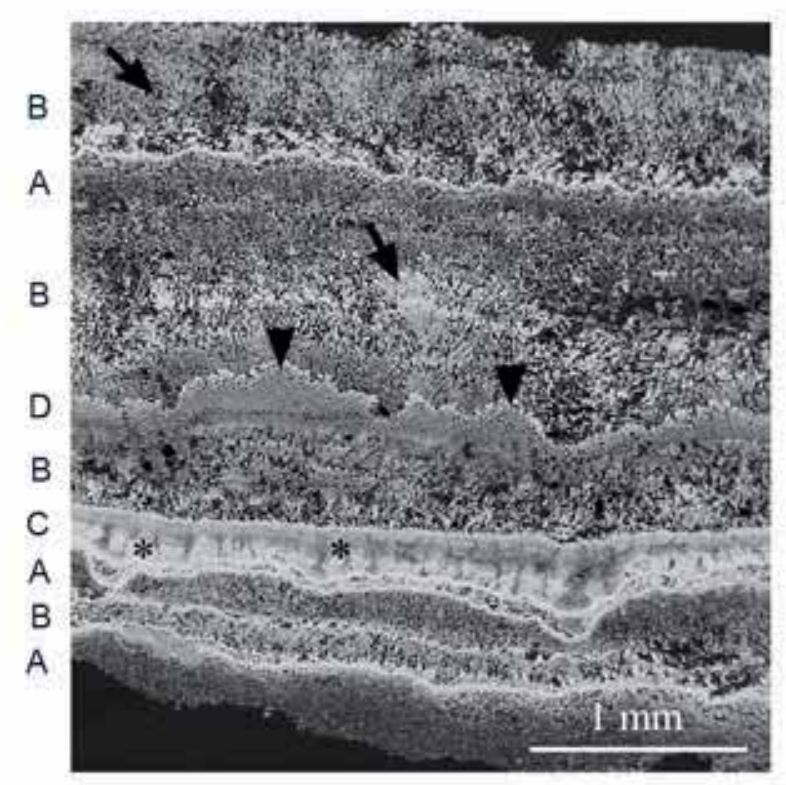

Fig. 4 

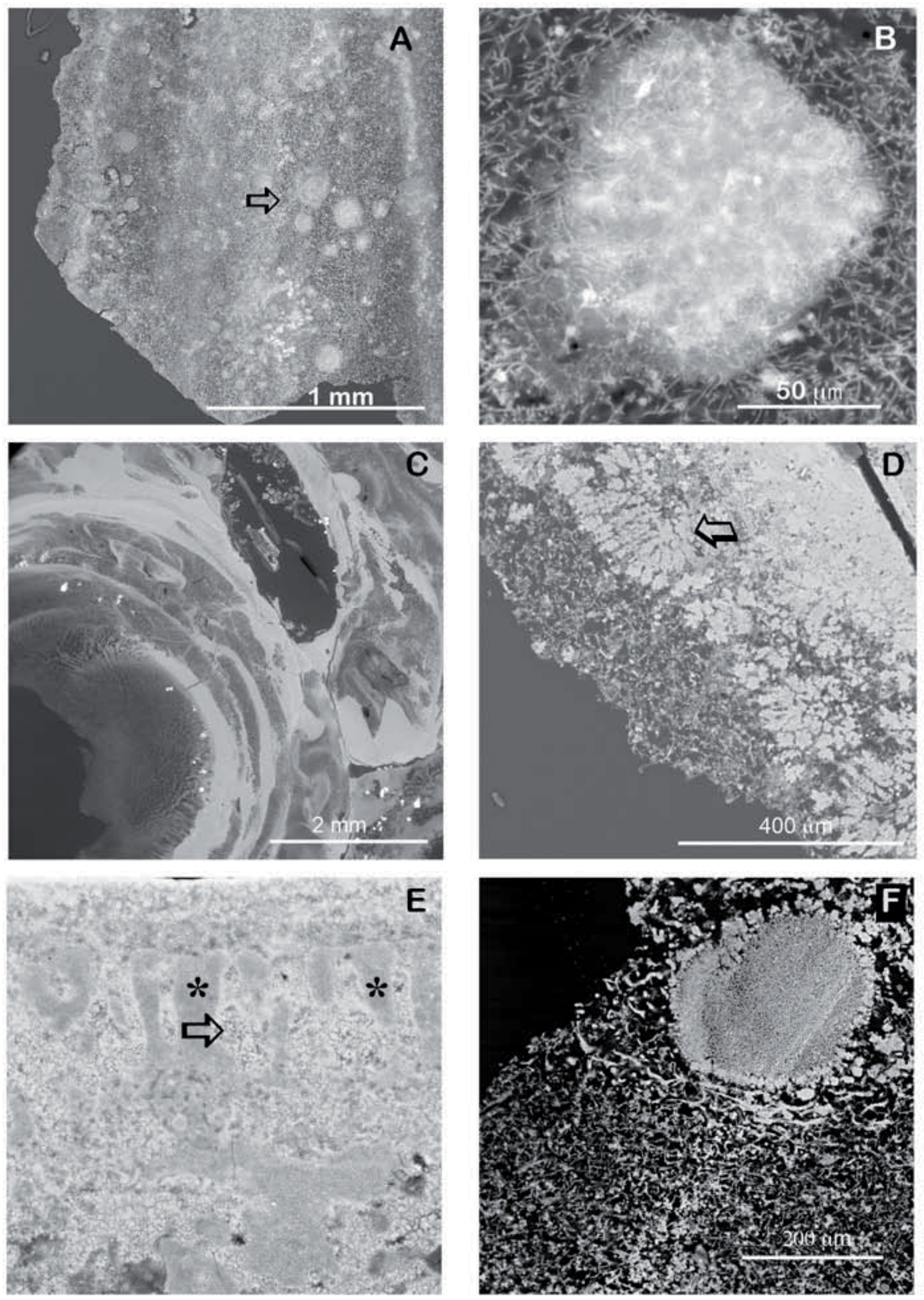

Fig. 5 

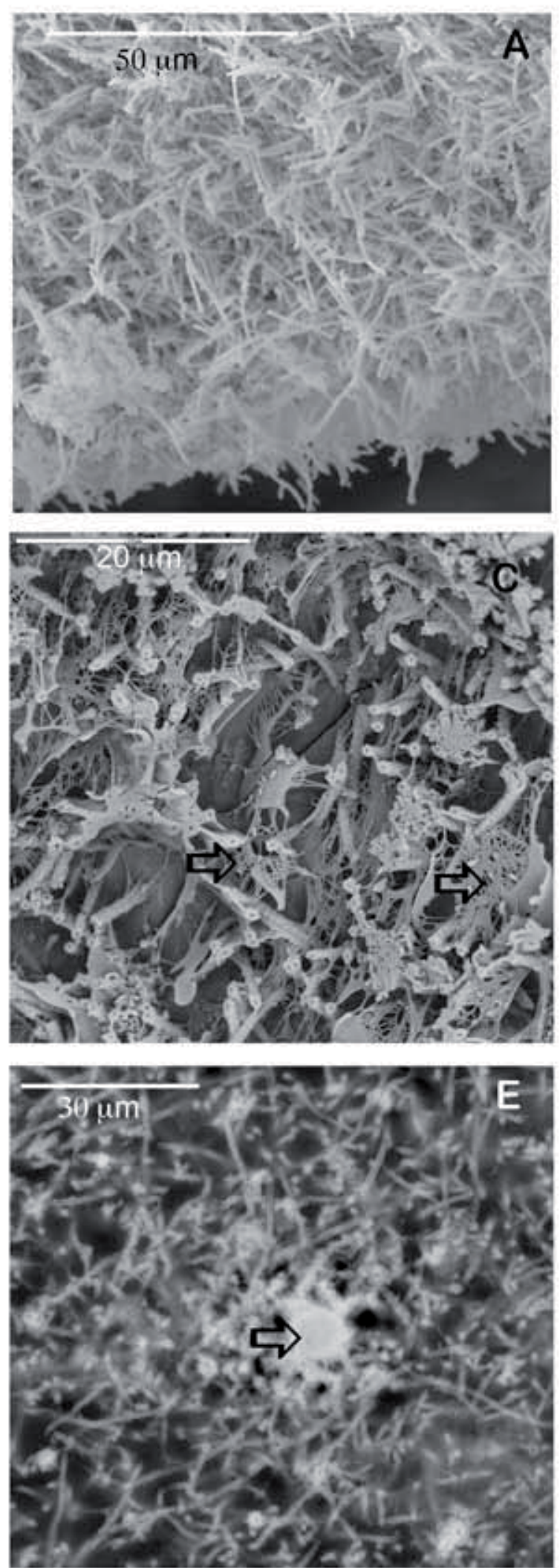
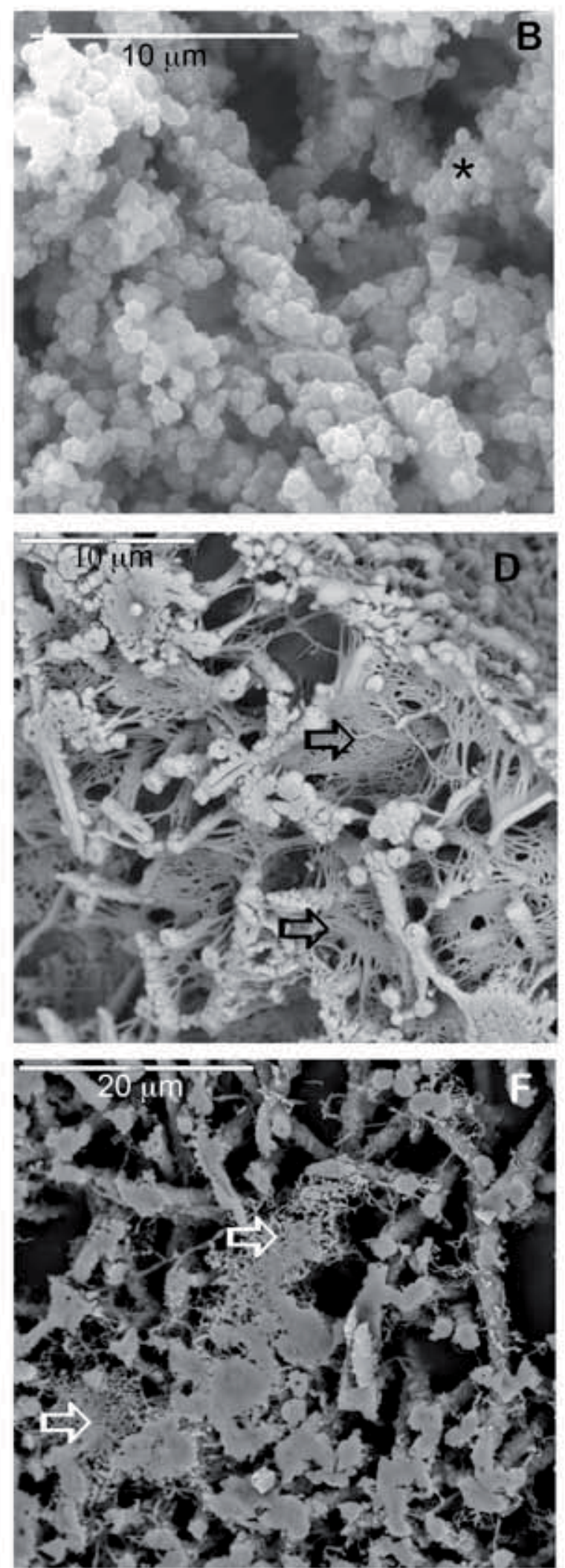

Fig. 6 

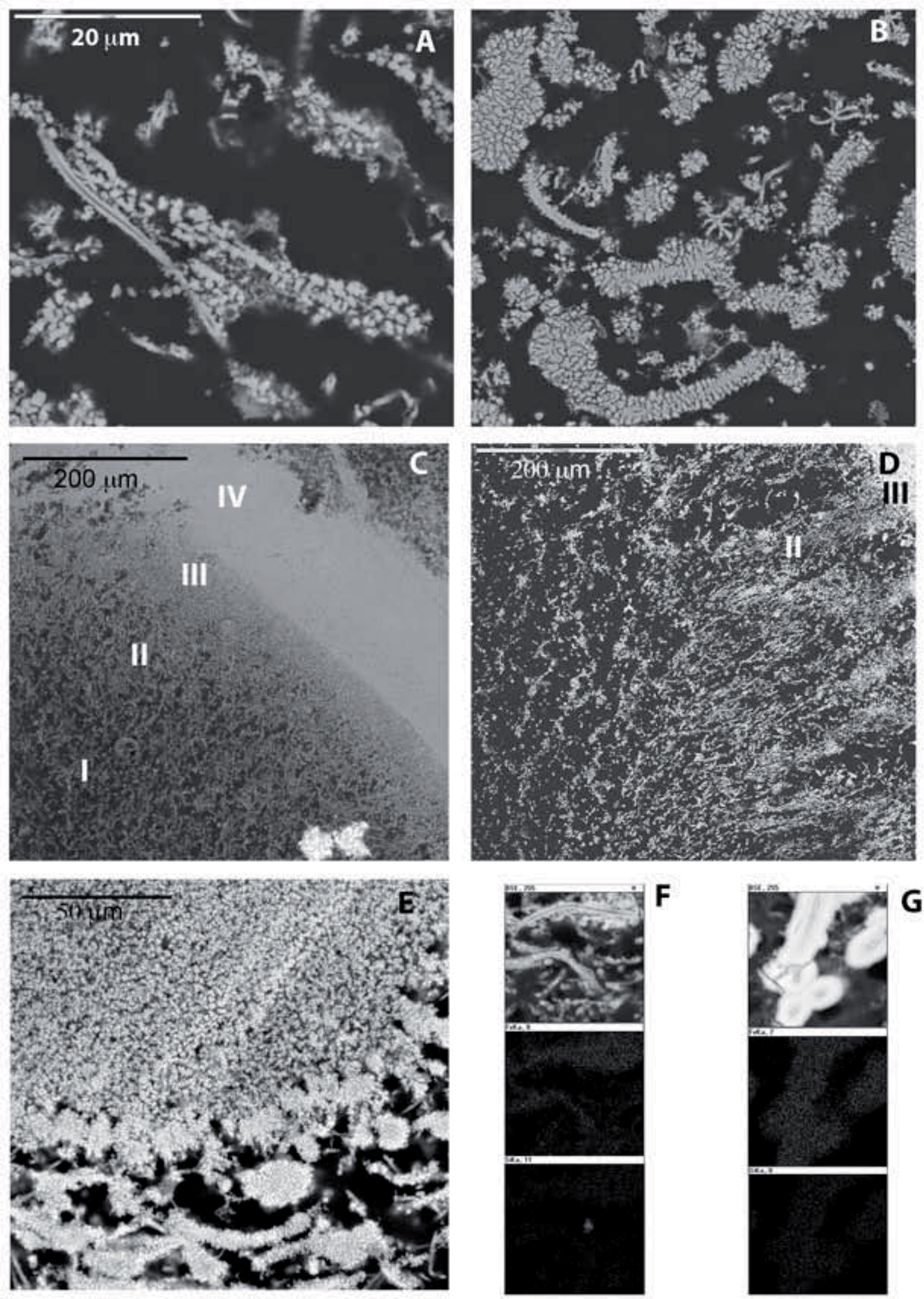

Fig. 7 

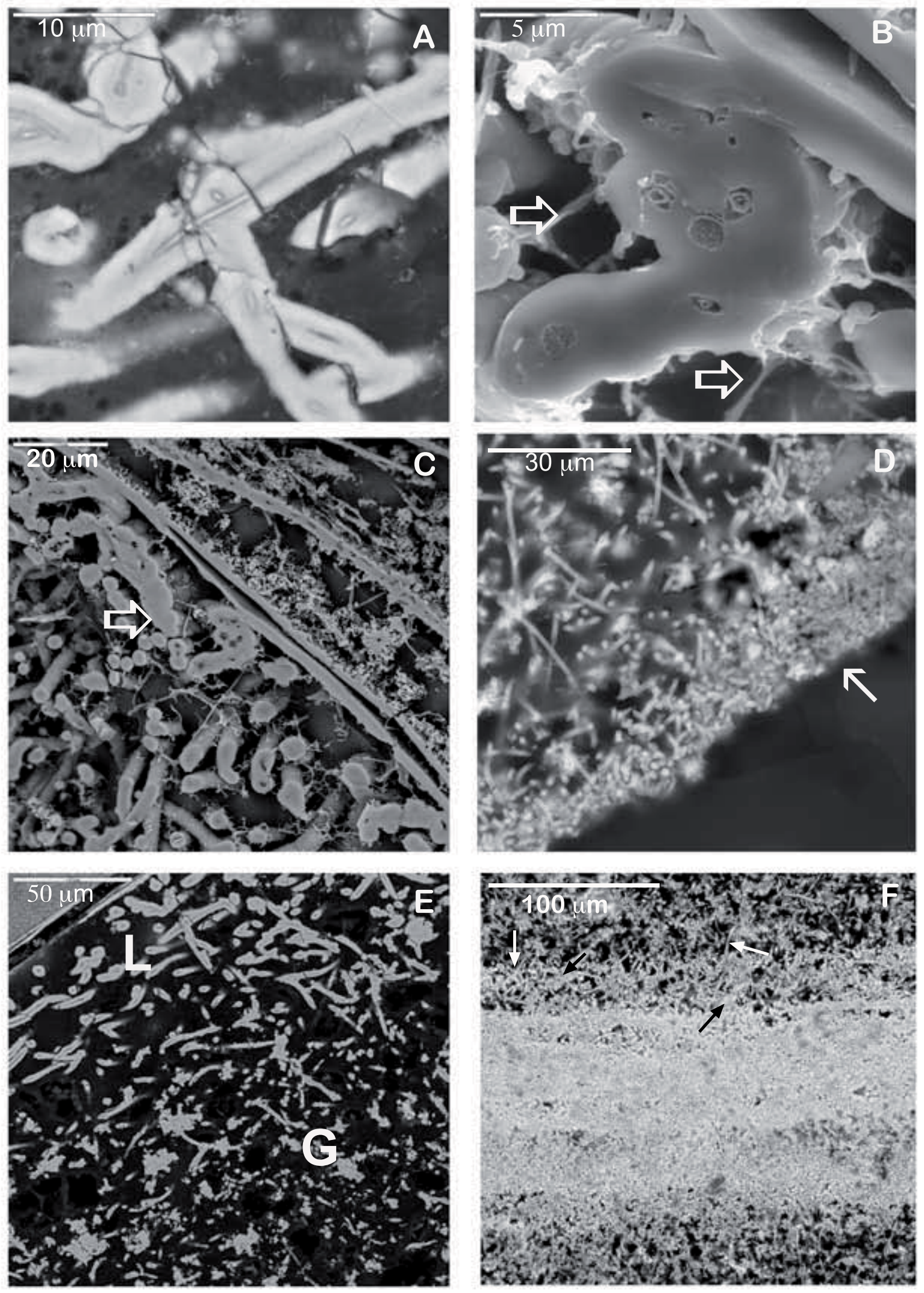

Fig. 8 


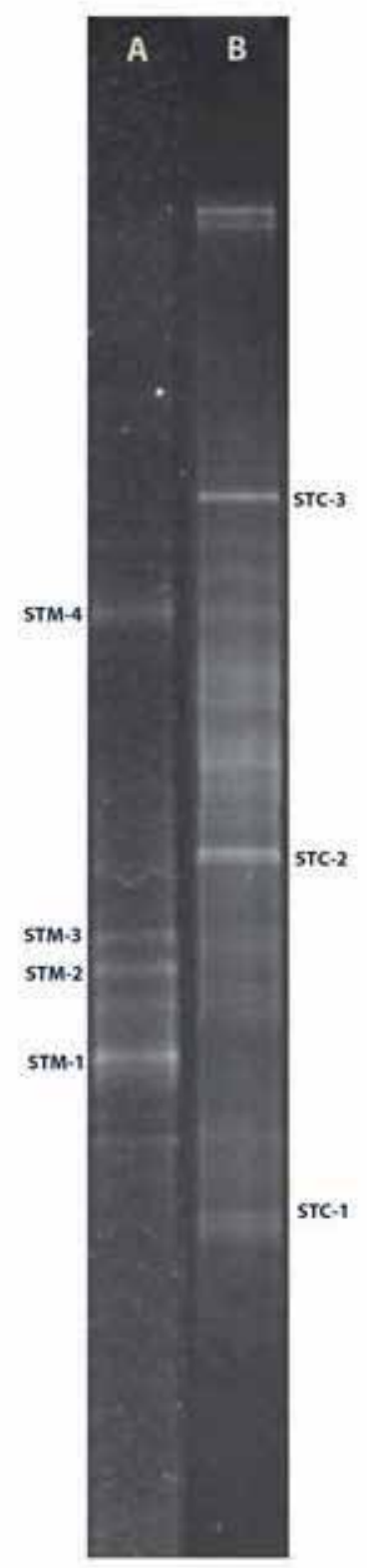

Fig. 9 